\title{
AN ANALYSIS OF POLITENESS STRATEGIES APPLIED BY THE MEMBERS OF UKM DEBAT,THE UNIVERSITY OF BENGKULU
}

\author{
Atikah Ayuningrum \\ Universitas Bengkulu \\ atikaha4@gmail.com \\ Rosnasari P \\ Universitas Bengkulu \\ rose.pulungan@gmail.com \\ Syafrizal S \\ Universitas Bengkulu \\ Syafrizal@unib.ac.id
}

\begin{abstract}
ABSTRAK
Penelitian ini bertujuan untuk mengetahui strategi kesopanan berdasarkan teori strategi kesopanan Brown dan Levinson yang digunakan oleh anggota UKM Debat, Universitas Bengkulu ketika berlatih debat. Subjek penelitian ini adalah anggota UKM Debat, Universitas Bengkulu yang terdiri dari delapan mahasiswa. Penelitian ini menggunakan deskriptif kualitatif sebagai metode penelitian dan data dikumpulkan dengan menggunakan transkrip dari rekaman video dan lembar observasi sebagai instrumen. Hasil dari analisis data menunjukkan bahwa peserta debat menggunakan semua strategi kesopanan tetapi tidak menggunakan semua sub strategi ketika berlatih debat, yaitu bald on record, strategi kesopanan positif, strategi kesopanan negatif, dan off record. Ada 28 tuturan yang termasuk ke dalam strategi kesopanan. Peserta debat paling banyak menerapkan strategi kesopanan positif, yang terjadi 19 kali $(67,8 \%)$. Bald on record dan off record terjadi 4 kali $(14,3 \%)$ dan yang terakhir strategi kesopanan negatif yang terjadi 1 kali $(3,6 \%)$. Strategi kesopanan positif mendapatkan posisi tertinggi pada data karena dalam berlatih debat, semua peserta debat telah mengetahui satu sama lain dan memiliki hubungan yang dekat.
\end{abstract}

Katakunci:debat, strategi kesopanan. 


\section{ABSTRACT}

The research is aimed at finding out the politeness strategies based on Brown and Levinson politeness strategies theory that used by the members of UKM Debat, the University of Bengkulu when practice debate. The subject of this research was the members of UKM Debat, the University of Bengkulu that consist of eight students. This research was using descriptive qualitative as the methodology and the data were collected by using transcript from video recorder and observation sheet as the instruments. The result of data analysis shows that the debaters use all of politeness strategies but they do not used all sub strategies when practice debate, which is bald on record, positive politeness strategy, negative politeness strategy, and off record. There were 28 utterances that consist of politeness strategy. The debaters mostly applied positive politeness strategy, which occurs 19 times $(67,8 \%)$. Bald on record and off record occur 4 times (14,3\%) and the last is negative politeness strategy which occurs 1 times (3,6\%). Positive politeness strategy gets the highest position in the data because in practicing debate, all debaters have known each other and have a close relationship.

Keywords: debate, politeness strategy.

\section{INTRODUCTION}

Language is a system of communication with other people using sounds, symbols, and words in expressing or conveying a meaning, idea or thought. Human and language can not be separated, because with language human can communicate with other people. Communication has an important role in society. In our daily life, a human of course use a language to be able to interact with other people. In fact, there are many components that should be learned by the people when they use a language. One of them is about politeness.

Politeness is an important aspect in human behaviour. It concerns all of attitude that influences people in their life. Sometimes, people do not think about it, while it is a key to make a good conversation and build a harmonious communication with other people. According to Brown and Levinson (1987), "politeness is how people behave in a way that attempts in considering the feelings of their addressee". From this definition we know that the speaker should pay attention with the hearer's feeling when the speaker says something. There is a strategy that can help us to fulfill that purpose, namely 'politeness strategy'.

The study of politeness strategy is basically the study of knowing the way of people use the language while they are having interaction or communication. The theory of politeness strategy expressed by Brown and Levinson (1987), they said there are four types of politeness strategy that sum up human "politenes" behavior. Those are bald on record, positive politeness, negative politeness, and off-record indirect stratagies.

The implementation of politeness strategies can happen wherever and whenever we communicate with other people. 
For example in debate. In University of Bengkulu, there was UKM Debat or Student's Activity Unit of Debate. It is the facility for University students to accomodate the idea and opinions of the students itself. In debate, the students can improve their ability in English while, think critically also consider about the politeness when they convey some opinions. From preliminary observation, the researcher found that the members of UKM Debat still use the sentences that less polite when they convey their opinion, even they too cornered their opponent.

The above explanation
becomes the researcher's background in proposing this research. The researcher would like to analyse the politeness strategies used by the members of UKM Debat, the University of Bengkulu when they practice debate based on Brown and Levinson (1987) politeness theory. The researcher is interested in investigating the politeness strategies applied by non-native speaker in debate, because in debate the debaters will stand in their position and work hard to convince other that their arguments are true without considering about politeness in order to be the winner in debate. Moreover this research is important for the researcher as English student to comprehend the politeness strategy theory in the real situation. According to the statement above, the researcher will do the research entitled "An Analysis of Politeness Strategies Applied by the Members of UKM Debat, the University of Bengkulu".
Based on the reason stated in the background of the study above, the statement of the study can be formulated as follows: "What are the politeness strategies applied by the members of UKM Debat, the University of Bengkulu based on Brown and Levinson politeness strategies theory?"

\section{METHOD}

In this research, the researcher used a descriptive qualitative research where the researcher will describe the use of politeness strategies that used by the members of UKM Debat, University of Bengkulu. Vanderstoep and Johnston (2009:310) in Archia (2014), define a qualitative research as a type of study which creates a descriptive text of the phenomena. They also said that the aim of the qualitative research is more descriptive than predictive. After the data has already collected, the researcher descriptively reported the finding.

The subject of this research was the members of UKM Debat, the University of Bengkulu that consist of 8 students. The researcher chose UKM Debat, the University of Bengkulu because it has some achievements such as, 1.) Indonesian delegates to World, University Debating Championship 2010 in Botswana, South Africa, 2.) Second novice best speaker NUDC 2017 in Semarang, 3.) Second winner SOVED Padang 2017, 4.) Third winner SOVED Padang 2017.

The instruments are needed to collect the data. The researcher used observation sheet and transcript from video 
recorder. Transcript of video recorder and observation sheet used for help the researcher to analyse the politeness strategies that used by the members of UKM Debat when they practice debate. When the researcher do the observation, the researcher acted as non-participant observer.

For reliability, the researcher worked with a co-rater. The researcher was accompanied by co-rater who has knowledge around the study investigated. The co-rater role in this research was to help the researcher in identifying the data in order to elude the subjectivity of research. To ensure the reliability of the data, the researcher used a formula from Sugiyono (2002).

$$
r=\frac{N \Sigma-(\Sigma)(\Sigma)}{\sqrt{\left\{N \Sigma^{2}-(\Sigma)^{2}\right\}\left\{N \Sigma^{2}-(\Sigma)^{2}\right\}}}
$$

\section{RESULTS ANDDISCUSSION}

\section{Results}

The data was taken on Mei 26, 2018 the duration is 1 hours 10 minutes and the subject of this research was 8 debaters. The result presented in a data analysis and the researcher provides a brief explanation and interprets the four strategies of politeness strategies.

\begin{tabular}{|c|c|c|c|}
\hline No. & $\begin{array}{l}\text { Types of } \\
\text { Politeness } \\
\text { Strategies }\end{array}$ & Frequency & $\begin{array}{c}\text { Number } \\
\text { of } \\
\text { Utteranc } \\
\mathrm{e}\end{array}$ \\
\hline 1. & $\begin{array}{l}\text { Bald on- } \\
\text { record }\end{array}$ & $4(14,3 \%)$ & $\begin{array}{l}98,110 \\
177,178\end{array}$ \\
\hline 2. & $\begin{array}{l}\text { Positive } \\
\text { politeness }\end{array}$ & $19(67,8 \%)$ & $\begin{array}{l}7,24 \\
28,36 \\
45,47 \\
58,68 \\
78,85 \\
87,90\end{array}$ \\
\hline
\end{tabular}

\begin{tabular}{|c|l|l|l|}
\hline & & & 105, \\
& & & 114, \\
& & & 223, \\
& & & 237, \\
& & & 239,254 \\
\hline \multirow{2}{*}{3.} & Negative & $1(3,6 \%)$ & 214 \\
& politeness & & \\
\hline \multirow{2}{*}{4.} & Off record & $4(14,3 \%)$ & 45,99, \\
& & & 178,211 \\
\hline \multicolumn{2}{|c|}{ Total } & 28 & \\
\hline
\end{tabular}

Table above presents the utterances of politeness strategies used by the members of UKM Debat, the University of Bengkulu when they practice debate. From the table, there are 28 utterances of politeness strategies. Among four strategies, positive politeness strategy is the strategy that most often used by the members of UKM Debat, the University of Bengkulu. As it is seen, positive politeness strategy is applied in as many as 19 times $(67,8 \%)$, it is followed by bald on record and off record which is applied as many as 4 times $(14,3 \%)$, and the last is negative politeness strategy which is applied as many as 1 times $(3,6 \%)$ in the members of UKM debat's utterances.

The members of UKM Debat, the University of Bengkulu used 4 times of bald on record strategy in sub strategy 1 which is cases of non-minimization of the face threat. It means that they used the sub strategy 1 which is cases of non-minimization of the face threat as $100 \%$, because there is no sub strategy 2 of bald on record in the utterances.

They used 19 times of positive politeness strategy in sub strategy 6 which is avoid disagreement 1 times (5,3\%), sub strategy 11 which is be optimistic 6 times $(31,6 \%)$ and sub strategy 12 which is include both speaker and hearer in the activity 12 times 
$(63,1 \%)$.

The members of UKM Debat, the University of Bengkulu also used 1 times of negative politeness strategy. In sub strategy 1 which is be conventionally indirect they used as many as 1 times (100\%), it means that only sub strategy 1 , be conventionally indirect that used by them, and there is no other sub strategies of negative politeness in the utterances.

They used 4 times of off record strategy. They only used sub strategy 9 , use metaphors as many as 4 times (100\%), because there is no other sub strategies of off record in the utterances.

Furthermore, as it is illustrated in the previous explanation that the positive politeness strategy is the most applied by the debaters, the utterances of its sub- strategies also have the largest rank. Include both speaker and hearer in the activity, which is the sub-strategy of positive politeness strategy is in the first position with 12 times $(42,8 \%)$ of 28 total utterances of politeness strategies. The second position is still positive politeness strategy with 6 times $(21,4 \%)$ of the whole utterances of politeness strategies, it is be optimistic.

They are followed by the other sub strategies which are applied less than 8 times and they have same times. There are cases of non-minimization of the face threat and use metaphors which occurs 4 times $(14,3 \%)$. And the last, be conventionally indirect and avoid disagreement which occurs 1 times $(3,6 \%)$ of the whole utterances.

\section{Discussion}

The 8 members of UKM Debat, the University of Bengkulu used politeness strategies in practice debate. From the result of the study, it could be recognized that the members of UKM Debat used all of politeness strategies but, they do not used all sub strategies of politeness strategies when they conveyed their arguments. The results of frequency politeness strategies used by the members of UKM Debat, the University of Bengkulu are bald on record, positive politeness strategy, negative politeness strategy, and off record.

The members of UKM Debat used bald on record in their utterances. Based on Brown and Levinson (1987), the utterance can be said as bald on record when the speaker have a powerful and does not fear retaliation or non-cooperation from hearer. This strategy usually used in urgent situation. In this study, the debaters used bald on record when they have a powerful chance to convey their argument, because that is time for them to convey the argument. The other reason is they used this strategy because they should convey their argument in limited time. So, they required to use this strategy to make their argument can understandable by the hearer clearly.

Positive politeness strategy was used by the member's of UKM Debat. The utterance can be said as a positive politeness strategy if the speaker shows a closeness and minimize the distance with the hearer in his/her utterance. Based on Brown and Levinson (1987) this strategy 
used by the people who have known each other in order to indicate a solidarity in which speaker have the same wants with the hearer. It is supported by Yule's theory (1996) the tendency to use positive politeness forms is emphasizing closeness between the hearer and the speaker and it can be seen as a solidarity strategy.

In this study, positive politeness strategy is the strategy that most frequently used by the debaters in practice debate. A close distance between them make all debaters use this strategy, because they have known each other. It will be different if the speaker and hearer have a social distance. It occurs in the study from Maulidiyah (2016) entitled "Face Threatening Acts and Politeness Strategy Performed by Debaters at Debate.Org Website". The study from Maulidiyah showed that the debaters prefer to use negative politeness strategy rather than positive politeness strategy because, there is a social distance between them. They debated the motion in the cyber world and they do not face to face directly. It caused the debaters tend to not use positive politeness strategy.

Negative politeness strategy also used in this research. The utterance can be said as a negative politeness strategy if the speaker shows there is a social distance between the hearer in his/her utterance. This strategy concern with the respect behavior when the people do not have a close social distance. It is related with Leech's generosity maxim, when the speaker maximize the respect to other and minimize disrespect to other, the utterance can be said a polite utterance.

In this study, negative politeness strategy was the most rarely strategy that used by the members of UKM Debat, because all members have a close distance and they tend to show a closeness although in different team. Contrast with the study from Maulidiyah (2016) entitled "Face Threatening Acts and Politeness Strategy Performed by Debaters at Debate.Org Website". The negative politeness strategy had great amount than positive politeness strategy in this study. The debaters tend to showed their respect by using this strategy, because they do not have a close relationsip and they want to soften their utterances when they conveyed their argument.

The last strategy used by the members of UKM Debat is off record. Based on Brown and Levinson (1987), the utterance can be said as the strategy of off record if the speaker used the indirectly utterance and make the hearer interpret the different things from the speaker's intention. So, there is a hidden meaning in the utterance of off record and the speaker do not force the hearer to understand the meaning of the speaker's utterance. It is related to the Leech's tact maxim, if the speaker maximize the benefit for the hearer and minimize the benefit for the speaker, it can be said as a polite thing.

In this study, the debaters used off record strategy because they want to show the expression of disagreement but indirectly. So, the hearer will interpreted the 
utterance by themselves. It is also happen in the study from Gaspie (2014) entitled "Politeness Strategies in Disagreement used by English Department Students of Muhammadiyah University of Surakarta". They used this strategy to decrease the degree of uncomfortable when they showed disagreement to others and by using this strategy they could minimize a risk of their utterance.

\section{CONCLUSIONS}

It can be concluded that, there are 4 strategies used by the members of UKM Debat, the University of Bengkulu when they practice debate, those are bald on record, positive politeness strategy, negative politeness strategy, and off record. Almost $2 / 3$ of data, present the positive politeness strategy. This is the most frequently strategy used by them in practice debate. It is assumed because they have a close relationship and they have known each other. In this case, the distance really influences to choose the politeness strategies.

Furthermore, almost $50 \%$ of the data used sub strategy 12 of positive politeness strategy which is include both speaker and hearer in the activity. It is the most frequently sub strategy used by them. It seems that they want to appreciate the other debaters, although in different side. From all sub strategies of each strategies, they only used 6 sub strategies, those are cases of non-minimization of the face threat, avoid disagreement, be optimistic, include both speaker and hearer in the activity, be conventionally indirect, and use metaphors. They always repeated the same sub strategies when they convey their argument. It means that they only applied limited politeness strategy and less have variation sub strategy, because of many reasons.

\section{SUGGESTIONS}

From this study, there are some suggestions that can be given to others. First, for the learner whose major in English Department, it is expected to be useful for the learner as the reference and can give more information about politeness strategies used by the members of UKM Debat, the University of Bengkulu, especially for the learner who will conduct the study in the same field, it can be used as a guidance for them.

The second, for the future research it is suggested to do the study in debate that explore many strategies or have some variation of strategies and do the research about factors affecting the debaters of using limited politeness strategies when they practice debate.

The last, this study has the weakness that is the lack of theory that used to analyse the problems of politeness strategy. It is recommended for the future research to try using more than one theories to analyse the politeness strategies wider.

\section{REFERENCES}

Brown and Levinson. 1987. Politeness Some Universals in Languages Usage. London: Cambridge University Press.

Gaspie, Renaldo. 2014. Politeness Strategies in Disagreement 
used by English Department Students of Muhammadiyah University of Surakarta. Publication Article. School of Teacher Training and Education Muhammadiyah University of Surakarta.

Holmes, Janet. 2013. An Introduction to Sociolinguistics: fourth edition. New York. Routledge, Taylor and Francis Group.

Latifatun Na'imah, Anni. 2017. Politeness Strategies performed by Contestants in the Second US Presidential Debate. Thesis. English Education Department, Faculty of Tarbiyah and Teacher Training, State Islamic Institute (IAIN) of Tulungagung.

Leech, G. 1983. Principles of Pragmatics. New York: Longman Group UK Ltd.

Norra, R.N. 2015. An Analysis of Politeness Strategies in Her Movie. Thesis. English Letters Department, Letters and Humanities Faculty, State Islamic University (UIN) Syarif Hidayatullah, Jakarta.

Sapir, Edward. 1921. Language: An Introduction to the Study of Speech. New York. Harcourt, Brace. Reprint: Dover Books on Language, 2004.

Sari, D.M. 2014. A Socio-Pragmatic Analysis of Politeness Strategies Performed by Barack Obama and Hillary Clinton in the Democratic Debate Held on February 26, 2008. Thesis. English Language and Literature
Study Program, Faculty of Languages and Arts, Yogyakarta State University. Sugiyono. 2002. Metode Penelitian Administrasi. Bandung: CV Alfabeta.

Yule, George. 1996. Pragmatics. Oxford: Oxford University Press. 